\title{
Heterozygous Peripheral Myelin Protein 22-Deficient Mice Are Affected by a Progressive Demyelinating Tomaculous Neuropathy
}

\author{
Katrin Adlkofer, ${ }^{1}$ Regula Frei, ${ }^{1}$ Dirk H.-H. Neuberg, ${ }^{1}$ Jürgen Zielasek, ${ }^{2}$ Klaus V. Toyka, ${ }^{2}$ and Ueli Suter ${ }^{1}$ \\ 1/nstitute of Cell Biology, Department of Biology, Swiss Federal Institute of Technology, CH-8093 Zürich, Switzerland, and \\ 2Department of Neurology, Julius-Maximilians-University, D-97080 Würzburg, Germany
}

\begin{abstract}
Hereditary neuropathy with liability to pressure palsy (HNPP) is associated with a heterozygous 1.5 megabase deletion on chromosome 17 that includes the peripheral myelin protein (PMP) gene PMP22. We show that heterozygous PMP22 knock-out mice, which carry only one functional pmp22 allele and thus genetically mimic HNPP closely, display similar morphological and electrophysiological features as observed in HNPP nerves. As reported previously, focal hypermyelinating structures called tomacula, the pathological hallmarks of HNPP, develop progressively in young PMP $22^{+/ 0}$ mice. By following the fate of tomacula during aging, we demonstrate now that these mutant animals are also interesting models for examining HNPP disease mechanisms. Subtle electrophysiological abnormalities are detected in PMP2 $2^{+/ 0}$ mice $>1$ year old, and a significant number of abnormally swollen and degenerating tomacula are present. Thinly myelinated axons and supernumerary Schwann cells forming onion bulbs as finger-
\end{abstract}

prints of repeated cycles of demyelination and remyelination are also encountered frequently. Quantitative analyses using electron microscopy on cross sections and light microscopy on single teased nerve fibers suggest that tomacula are intrinsically unstable structures that are prone to degeneration; however, the severity of morphological and electrophysiological abnormalities in PMP22 $2^{+/ 0}$ mice is variable. These combined findings are reminiscent of the disease progression in HNPP and offer a possible explanation about why some HNPP patients develop a chronic motor and sensory neuropathy later in life that resembles demyelinating forms of Charcot-MarieTooth disease by both morphological and clinical criteria.

Key words: PMP22; peripheral myelin protein-22; peripheral neuropathy; myelin; Charcot-Marie-Tooth disease; CMT; hereditary neuropathy with liability to pressure palsies; HNPP; tomaculous neuropathy; demyelination
The most common inherited human peripheral neuropathy, Charcot-Marie-Tooth disease (CMT) (Skre, 1974), can be grouped on the basis of genetic, electrophysiological, morphological, and clinical criteria. Molecular genetic analysis reveals that point mutations and aberrant expression of the myelin proteins peripheral myelin protein 22 (PMP22), protein zero (P0), and connexin32 (Cx32) lead to CMT types 1A (CMT1A), 1B (CMT1B), and X1 (CMTX1), respectively (for review, see Suter and Snipes, 1995).

CMT1A and hereditary neuropathy with liability to pressure palsies (HNPP) are two inherited autosomal dominant peripheral neuropathies that are both associated with genomic rearrangements on human chromosome 17 (Lupski et al., 1991; Raeymaekers et al., 1991). Duplication of a 1.5 megabase region spanning chromosome 17p11.2-p12 leads to CMT1A, whereas the reciprocal deletion causes HNPP (Pentao et al., 1992; Chance et al., 1993; Reiter et al., 1996). The PMP22 gene (PMP22) is located within the affected region and is likely to play a crucial role in these neuropathies (Patel et al., 1992). This hypothesis is supported by the finding that specific missense mutations within the PMP22 gene lead either to a CMT1A-like phenotype or the congenital

Received Feb. 24, 1997; revised March 18, 1997; accepted April 8, 1997.

This work was supported by a grant from the Swiss National Science Foundation (U.S.). We thank Corinne Zgraggen for excellent technical assistance, Heide MayerRosa for expert photographical help, Dr. Sara Sancho for stimulating discussions, and Dr. Verdon Taylor for critically reading this manuscript.

Correspondence should be addressed to Dr. Ueli Suter, Institute of Cell Biology, Swiss Federal Institute of Technology, ETH-Hönggerberg, CH-8093 Zürich, Switzerland.

Copyright (C) 1997 Society for Neuroscience $\quad 0270-6474 / 97 / 174662-10 \$ 05.00 / 0$ hypomyelinating peripheral neuropathy Déjérine-Sottas Syndrome (DSS) (for review, see Suter and Snipes, 1995). In the mouse, the pmp22 gene is located on chromosome 11, and dysmyelinating neuropathies attributable to pmp22 mutations have been found in the natural mouse mutants Trembler and Trembler-J (Suter et al., 1992a,b).

Biochemically, PMP22 is a hydrophobic $22 \mathrm{kDa}$ glycoprotein component of PNS myelin (Snipes et al., 1992) sharing structural features with proteolipid protein (PLP), the major protein of CNS myelin (Suter et al., 1993). In addition to the likely function of PMP22 as a structural component of myelin, in vitro studies suggest a role for PMP22 in the regulation of cell proliferation and apoptosis (Fabbretti et al., 1995; Zoidl et al., 1995). Consistent with this hypothesis, PMP22 transcripts have been found in various embryonic and adult tissues (Welcher et al., 1991; Baechner et al., 1995; Parmantier et al., 1995). Furthermore, PMP22 belongs to a widely expressed gene family whose members are differentially regulated during the cell cycle (Marvin et al., 1995; Taylor et al., 1995; Ruegg et al., 1996; Taylor and Suter, 1996).

To clarify the function of PMP22, the pmp22 gene was disrupted using gene-targeting techniques in mice (Adlkofer et al., 1995). From the results obtained in human genetics, it was anticipated that heterozygous PMP22 knock-out $\left(\mathrm{PMP} 22^{+/ 0}\right.$ ) mice would potentially mimic HNPP if haploinsufficiency of the PMP22 locus alone is responsible for developing the disease. Thus, it was assumed that PMP $22^{+/ 0}$ mice might represent an accurate model for studying disease mechanisms in this disorder.

The first symptoms of HNPP are usually observed in adolescence, manifested as a neuropathy that is characterized by recurrent pres- 
Table 1. Electrophysiological findings in 12- to 14-month-old $P M P 22^{+/ 0}$ and wild-type mice (mean \pm SD)

\begin{tabular}{|c|c|c|c|c|c|c|c|c|c|}
\hline \multirow[b]{2}{*}{ Genotype } & \multicolumn{2}{|c|}{ Facial nerve } & \multicolumn{3}{|c|}{ Sciatic nerve proximal stimulation } & \multicolumn{3}{|c|}{ Sciatic nerve distal stimulation } & \multirow{2}{*}{$\begin{array}{l}\text { Motor } \\
\text { NCV } \\
(\mathrm{m} / \mathrm{sec})\end{array}$} \\
\hline & $\begin{array}{l}\text { Latency } \\
(\mathrm{msec})\end{array}$ & $\begin{array}{l}\text { Amplitude } \\
(\mathrm{mV})\end{array}$ & $\begin{array}{l}\text { M-latency } \\
\text { (msec) }\end{array}$ & $\begin{array}{l}\text { M-amplitude } \\
(\mathrm{mV})\end{array}$ & $\begin{array}{l}\text { F-latency } \\
(\mathrm{msec})\end{array}$ & $\begin{array}{l}\text { M-latency } \\
(\mathrm{msec})\end{array}$ & $\begin{array}{l}\text { M-amplitude } \\
(\mathrm{mV})\end{array}$ & $\begin{array}{l}\text { F-latency } \\
(\mathrm{msec})\end{array}$ & \\
\hline $\begin{array}{l}P M P 22^{+/ 0} \\
(n=9)\end{array}$ & $1.0 \pm 0.1$ & $15 \pm 6$ & $1.8 \pm 0.3$ & $7 \pm 3^{*}$ & $4.6 \pm 0.5$ & $1.0 \pm 0.3$ & $9 \pm 6^{*}$ & $5.1 \pm 0.5$ & $32 \pm 7$ \\
\hline $\begin{array}{l}P M P 22^{+/+} \\
(n=14)\end{array}$ & $1.1 \pm 0.2$ & $14 \pm 3$ & $1.6 \pm 0.2$ & $12 \pm 4$ & $4.6 \pm 0.6$ & $1.0 \pm 0.2$ & $13 \pm 4$ & $5.0 \pm 0.6$ & $40 \pm 14$ \\
\hline
\end{tabular}

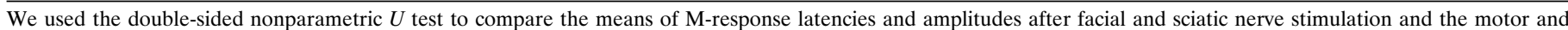
mixed afferent NCVs between $P M P 22^{+/ 0}$ and wild-type mice. A $p<0.05$ was considered statistically significant $(*)$.

sure palsies precipitated by minor trauma to peripheral nerves (De Jong, 1947; Davies, 1954; Earl et al., 1964; Staal et al., 1965). Pathological changes in HNPP sural nerve biopsies include tomacula and, rarely, segmental demyelination (Meier and Moll, 1982; Dyck et al., 1993; Amato et al., 1996). Although the histopathological features of HNPP and CMT are distinctly different, they share overlapping clinical features that may confuse the diagnosis of the two disorders (Windebank, 1993; Roa et al., 1995).

In this study, we compare the reported pathogenesis of HNPP to PMP $22^{+/ 0}$ mice. These animals exhibit similar myelin abnormalities as described in HNPP. Moreover, we observed morphological and electrophysiological changes in PMP $22^{+/ 0}$ mice with progressing age that are comparable to the disease course in humans. Finally, we show that tomacula are likely to represent a labile prestage to demyelination, thus providing a possible explanation for the overlapping clinical features in CMT and HNPP.

\section{MATERIALS AND METHODS}

Animals and determination of genotype. Mice used in all experiments were obtained from our own breeding strain Agouti SV129 EV/C57BL/6. Genotypes of PMP $22^{+/ 0}$ and wild-type mice were assessed by Southern blot analysis of genomic DNA from tail biopsies (Adlkofer et al., 1995). Electrophysiology. We studied 9 PMP $22^{+/ 0}$ mice at age $375-426 \mathrm{~d}$ and 14 PMP $22^{+/+}$mice at age 358-408 d, using previously described techniques (Adlkofer et al., 1995; Magyar et al., 1996). In brief, mice were anesthetized with a neuroleptic/analgesic combination (Hypnorm; Janssen, Beerse, Belgium). Body temperature as measured under the abdomen with a thermistor was allowed to equilibrate at $33.5-34.5^{\circ} \mathrm{C}$ under a heating lamp before measurements using a Medelec 92 a electromyograph (Medelec, Surrey, UK) were started. Steel needle electrodes (DISA 13 L60 and 64) were placed subcutaneously. For facial nerve studies, stimulating electrodes were placed in the left outer ear canal (active electrode) and behind the ear (inactive electrode). A pair of steel recording electrodes (Picker, Munich, Germany) was placed in the whisker muscles, with the active electrode ipsilateral to the stimulation side. For sciatic nerve studies, a pair of stimulating electrodes (DISA 13L64) was placed in the left sciatic notch and $2 \mathrm{~cm}$ laterally (proximal stimulation). A second pair of stimulating electrodes (Picker) was inserted subcutaneously along the tibial nerve just above the ankle ("distal stimulation"). Recording electrodes (Picker) were placed in the skin close to the hallux and between digits 2 and 3 of the left foot. Near-nerve localization of the stimulating cathode was ascertained by determining the lowest possible threshold current to elicit a motor action potential, and studies were performed with a current $50 \%$ higher than that needed to elicit maximal stimulation. All potentials were immediately recorded on recording paper, and data calculations from printed records were double-checked. No systematic errors in latency or amplitude determinations could be detected. Latencies and amplitudes of the facial and sciatic compound muscle action potentials (M-response) were determined. In addition, we measured the F-wave elicitability and latency in the sciatic nerve. Mixed afferent sciatic nerve potential latencies were recorded at the sciatic notch with averaging of potentials after stimulation at the distal stimulation site. "Mixed afferent" denotes that the compound nerve action potentials included orthodromically stimulated sensory fibers and antidromically stimulated motor fibers. Motor and mixed afferent nerve conductance velocities (NCVs) were calculated from the sciatic nerve latency mea- surements. The distance between stimulation sites was measured with a caliper on the slightly bent limb of the mouse.

Tissue preservation and electron microscopy. Electron and light microscopy of quadriceps nerve of transcardially perfused mice $(4 \%$ paraformaldehyde $/ 2 \%$ glutaraldehyde in $0.1 \mathrm{~m}$ cacodylate buffer, $\mathrm{pH}$ 7.5) were performed as described (Martini et al., 1990; Fruttiger et al., 1995). For light microscopy, semi-thin sections were obtained from the same embedded nerve, cut in $2 \mu \mathrm{m}$ sections, and stained with alkaline toluidine blue.

Teased nerve fiber preparation. The quadriceps branch of the femoral nerve was used for single axon fiber preparation. Femoral nerves were dissected from transcardially perfused mice, and their connective tissue sheath was removed and preteased into small bundles, followed by osmification $\left(2 \% \mathrm{OsO}_{4}\right.$ in $0.1 \mathrm{M}$ cacodylate buffer) for $2 \mathrm{hr}$, dehydration in an ascending acetone series, and immersion in Spurr medium overnight at $4^{\circ} \mathrm{C}$. Single fibers were obtained by teasing in embedding medium. Light microscopy was performed on a Zeiss Axiophot using phasecontrast optics (Martini et al., 1995).

Immunohistochemistry. Nerve fibers were dissected from femoral nerve of mice intracardially perfused with $4 \%$ paraformaldehyde in $0.1 \mathrm{M}$ cacodylate buffer, $\mathrm{pH}$ 7.4. Dissected fibers were incubated in $6.6 \mathrm{~nm}$ rhodamine-conjugated phalloidin (Molecular Probes Europe BV, Leiden, Netherlands) in $1 \%$ Triton X-100/PBS for $1 \mathrm{hr}$ at room temperature. The nerves were rinsed in PBS, teased in Citifluor antifadent AF-1 (Chemical Laboratory University of Kent, Canterbury, Kent, UK) on an uncoated glass slide, coverslipped, and examined by fluorescence microscopy using a Zeiss Axiophot.

Statistical analyses. For statistical analysis of morphological features, five animals were used for each age group. Between 80 and 100 internodal segments were counted from each animal and included in the teased nerve fiber statistics. Cross sections were obtained at the level where the quadriceps nerve branches out of the femoralis nerve. Approximately 100 axon/Schwann cell units were counted and analyzed for each animal. The data were analyzed by the nonparametric Mann-Whitney $U$ test using Statview II software for morphology analysis and Instat software for electrophysiology (Graph Pad, San Diego, CA). A $p$ value $\leq 0.05$ is considered to be significant.

\section{RESULTS}

\section{Electrophysiology of aged PMP22 ${ }^{+/ 0}$ mice}

We have shown previously that no electrophysiological abnormalities are detectable in 10-week-old PMP $22^{+/ 0}$ mice (Adlkofer et al., 1995); however, 12- to 14 month-old PMP $22^{+/ 0}$ mice exhibited significantly reduced $\mathrm{M}$-response amplitudes in the sciatic nerve as compared with age-matched control mice, whereas motor and mixed afferent latencies, F-wave latencies, duration of $\mathrm{M}$ - and F-responses, and NCVs were not significantly changed (Table 1).

\section{Morphological analysis by light microscopy}

Only a few hypermyelinated axons are observed in the quadriceps nerves of $24-\mathrm{d}$-old PMP $22^{+/ 0}$ mice, whereas the number of focally hypermyelinated axons is significantly increased in 10 week-old PMP22 ${ }^{+/ 0}$ animals (Adlkofer et al., 1995). To evaluate further agerelated morphological changes in peripheral nerves of PMP22 $2^{+/ 0}$ mice, $2 \mu \mathrm{m}$ semi-thin sections of quadriceps nerves of 5-, 10-, and 15 month-old wild-type and PMP $22^{+/ 0}$ mice were stained with alkaline 


\section{PMP22wt}

\section{a $5 \mathrm{~m}$}

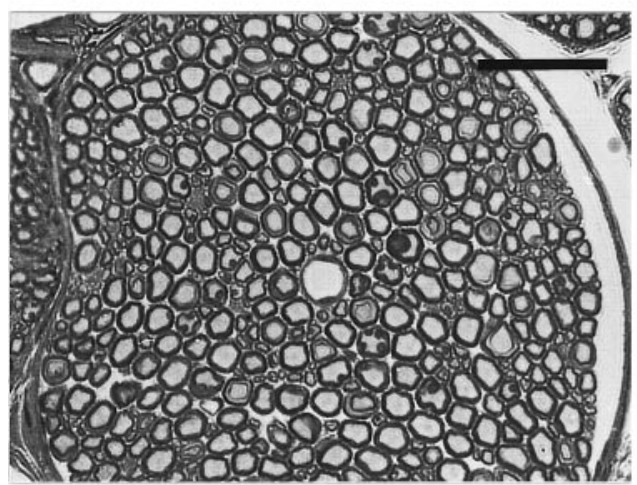

c $10 \mathrm{~m}$

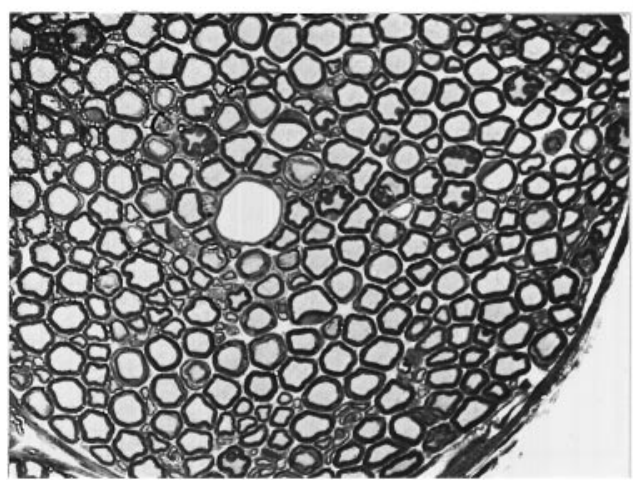

e $15 \mathrm{~m}$

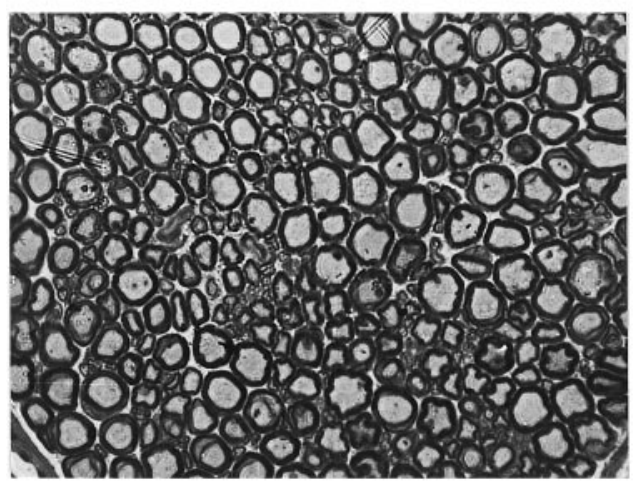

PMP22+/0

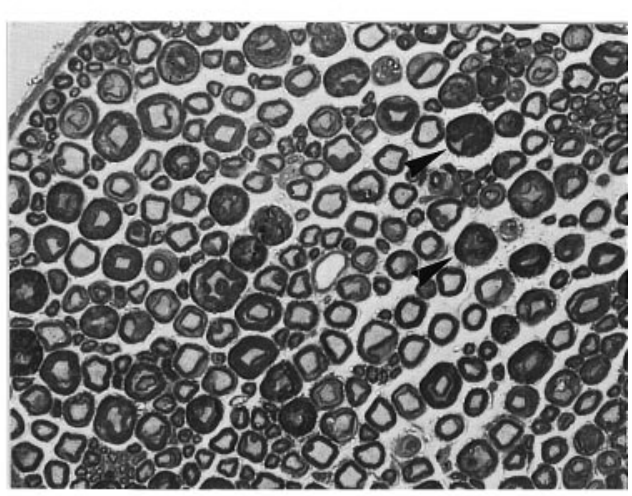

d $10 \mathrm{~m}$

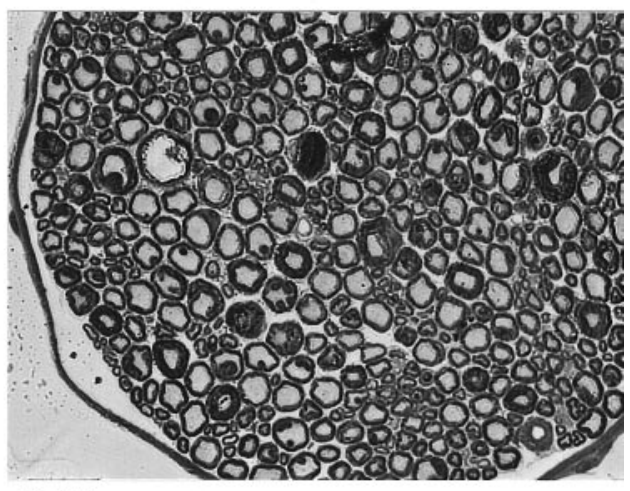

f $15 \mathrm{~m}$

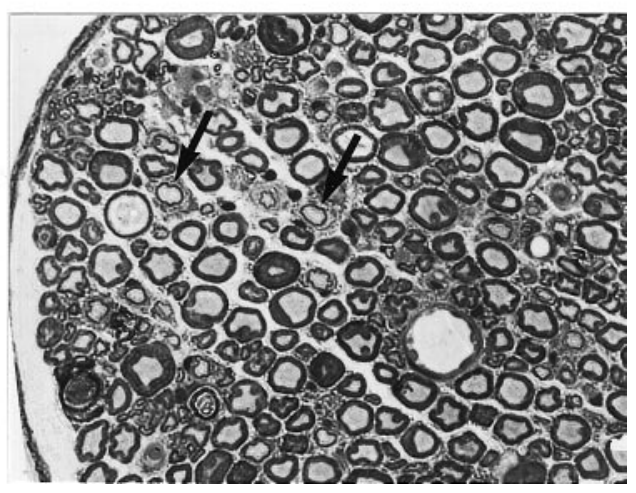

Figure 1. Alkaline toluidine blue staining of quadriceps nerve cross sections of wild-type and PMP $22^{+/ 0}$ mice of different ages. Two micrometer cross sections of the quadriceps nerve show no myelin abnormalities in 5-, 10-, and 15-monthold control animals $(a, c, e)$. In PMP $22^{+/ 0}$ littermates, myelinated fibers with abnormal thick myelin sheaths are visible in transverse sections of quadriceps nerves (arrowheads) ( $b, d, f)$. In 15-month-old mutants, onion bulb formation is observed (arrows) $(f)$. Scale bar, $25 \mu \mathrm{m}$.

toluidine blue (Fig. 1). In 5- and 10 month-old mutant animals, myelin sheaths of increased thickness compared with the caliber of the corresponding axons were observed regularly (Fig. 1b, $d$ ). Hypermyelination was still seen frequently in 15-month-old PMP $22^{+/ 0}$ mice, but in addition, axons with abnormally thin myelin surrounded by redundant Schwann cells were found. Such onion bulb structures are indicative of demyelination and remyelination processes affecting specific axon-Schwann cell units and were often observed in clusters (Fig. $1 f$ ). Interestingly, the saphenous nerve was much less affected in PMP $22^{+/ 0}$ mice of all ages examined. This sensory cutaneous branch of the femoral nerve appeared almost normal in young mutant animals, and only some signs of hypermyelination were found at older ages (data not shown). No obvious peripheral nerve abnormalities were observed in wild-type littermates (Fig. 1a,c,e).

\section{Electron microscopy analysis}

To confirm the data obtained by light microscopy, ultrastructural analysis was performed using electron microscopy. Various forms of hypermyelinated axons were observed in 5-, 10- and 15-monthold PMP $22^{+/ 0}$ mice. One class of hypermyelination seems to be caused by excessive wrappings of the myelin sheath around the axon resulting in an abnormal number of myelin lamellae (Fig. $2 b$ ). Another form is characterized by internal or external wrapping of redundant myelin loops (Fig. $2 d$ ). Such myelin figures may arise initially from infoldings of myelin leading to frequently encountered myelin islands in mutant nerves (Fig. 2c). Similar figures are occasionally also seen in wild-type nerves (data not shown), but they were much more prominent in mutant animals. 
a PMP22wt

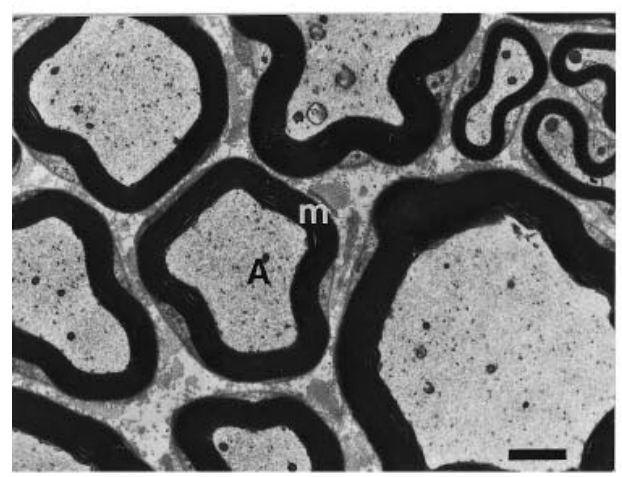

c PMP22+/0

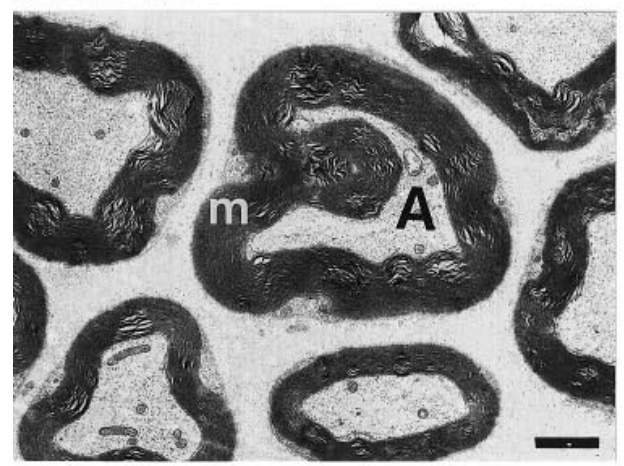

e PMP22+/0

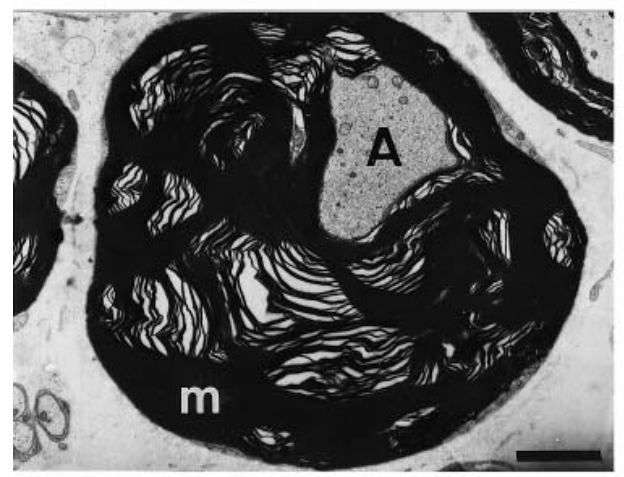

g PMP22+/0

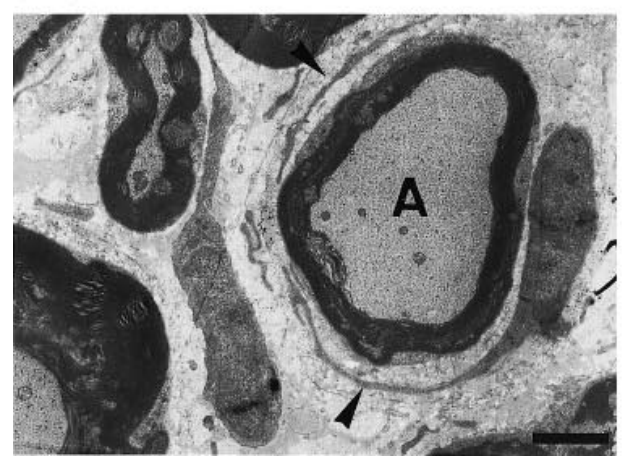

b $\mathrm{PMP} 22^{+/ 0}$

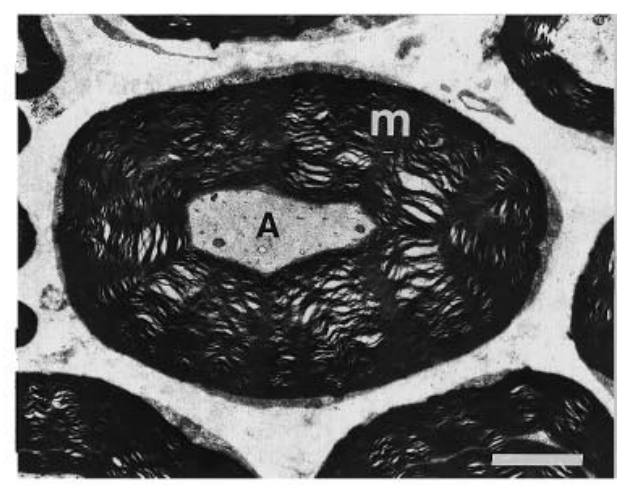

d PMP22+/U

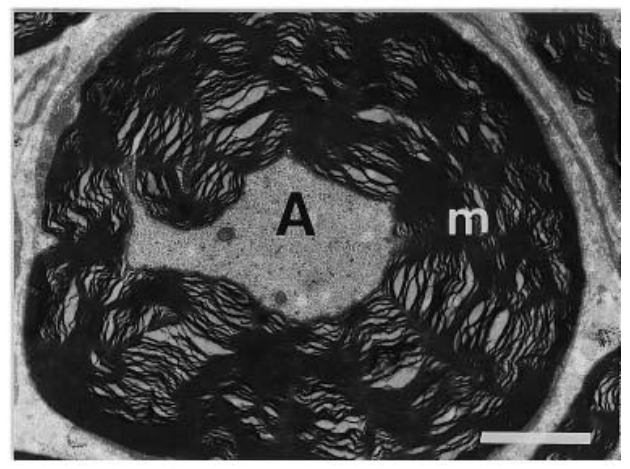

\section{$f$ PMP22+/0}

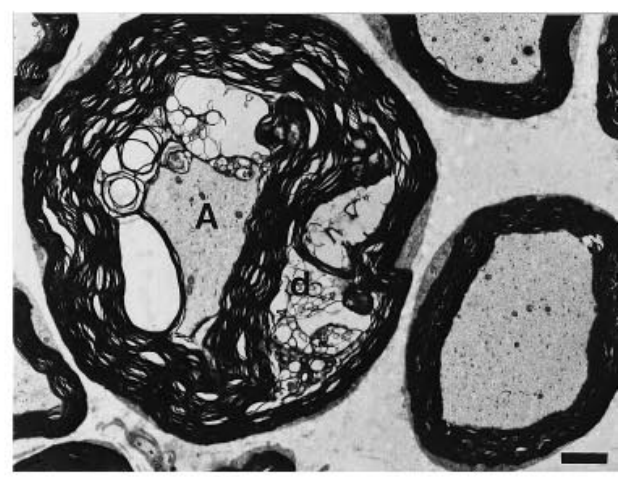

h PMP22+/0

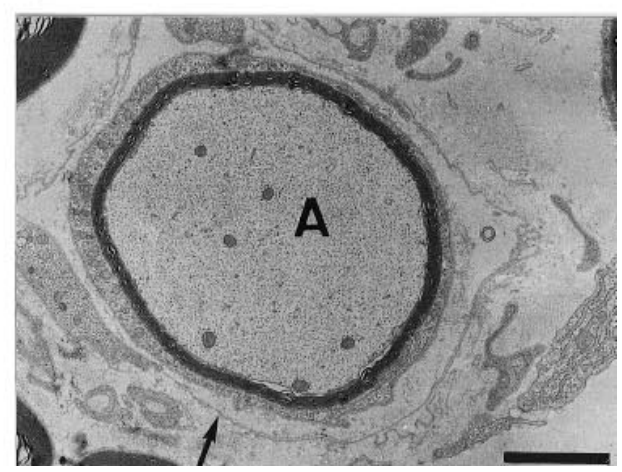

Figure 2. Ultrastructure of abnormal myelin in PMP $22^{+/ 0}$ mice. Cross sections from the quadriceps nerve of a wild-type mouse (a), a 10-month-old PMP22 $/ 0$ mouse showing hypermyelination attributable to excessive wrapping of the myelin sheath $(b)$, a 10 -month-old PMP $22^{+/ 0}$ animal illustrating the invagination of the myelin sheath as a potential start of focal hypermyelination (c), a 5-month-old PMP $22^{+/ 0}$ mouse showing intermyelin infolds forming a hypermyelin structure $(d)$, a 10-month-old PMP $22^{+/ 0}$ mouse showing a hypermyelin structure with displaced axon $(e)$, a 10 -month-old PMP $22^{+/ 0}$ mouse showing degenerating hypermyelin $(f)$, and a 15 -month-old PMP22 $2^{+/ 0}$ mouse showing thinly myelinated axons with concentric Schwann cell processes $(g$, arrowheads) and basal laminae $(h$, arrow) forming onion bulbs. Axons $(A)$, compact myelin $(m)$, and degenerating myelin $(d)$ are marked. Scale bar, $2.5 \mu \mathrm{m}$. 


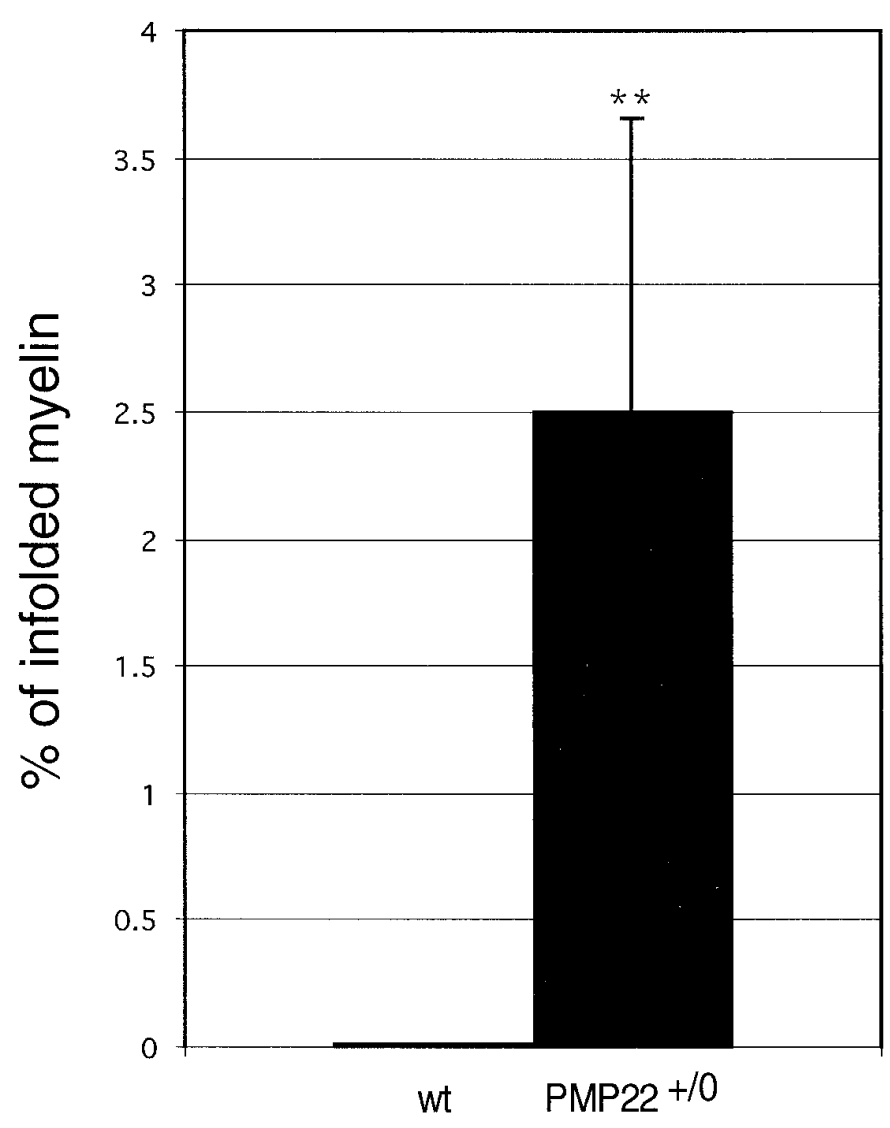

Figure 3. Quantitation of prominent infoldings of the myelin sheath in 10 -month-old PMP $22^{+/ 0}$ mice. Significant numbers of myelin infolds that are extended to more than half of the axon diameter are observed on cross sections of quadriceps nerves of 10 -month-old PMP $22^{+/ 0}$ mice $(n=5)$. In contrast, such prominent structures were not observed in wild-type littermates $\left(n=2 ;{ }^{* *} p \leq 0.01\right.$; one-sided $U$ test $)$.

To account for this fact in the quantitative analysis, we used the criterion that only myelin infolds that were extended to more than half of the axon diameter were considered (Fig. 3).

In PMP $22^{+/ 0}$ mice older than 10 months, additional forms of myelin degeneration were observed. Hypermyelinated structures were often nonconcentrically arranged around the axon, and the axon appeared compressed (Fig. 2e). Similar to the findings in HNPP biopsies, a characteristic splitting of the major dense line and vacuolation of myelin leading to an intramyelin edema was frequently seen (Fig. 2f) (Madrid and Bradley, 1975). These features may be interpreted as early signs of myelin degeneration. Moreover, Schwann cells with phagocytized myelin debris present in the cytoplasm were observed (not shown). Some myelin sheaths looked abnormally thin, and such profiles were surrounded by Schwann cells and Schwann cell processes forming cellular or basal lamina-type onion bulbs (Fig. $2 g, h$ ). Large caliber axons devoid of any myelin were not detected (data not shown). In general, increased myelin splitting after routine specimen preparation was commonly observed in PMP22-deficient animals, possibly indicating a weakened myelin structure (Fig. 2; data not shown).

\section{Statistical analysis of myelin abnormalities in quadriceps nerve cross sections}

Different forms of abnormal myelin were quantitated to assess disease progression by comparing 5-, 10-, and 15-month-old
PMP $22^{+/ 0}$ mice. Five animals of each age group were analyzed, and generally a relatively high variability was observed (Fig. 4).

In 5-month-old PMP $22^{+/ 0}$ mice, $79.2 \pm 12.5 \%$ (mean $\left.\pm \mathrm{SD}\right)$ of the myelinated axon-Schwann cell units appeared normal, and $24.6 \pm 8.7 \%$ showed definitive signs of hypermyelination. Degenerating hypermyelin and onion bulb structures were barely detectable $(\leq 1 \%)$. In 10 -month-old mutant mice, $15.7 \pm 7.7 \%$ of the myelinated axon-Schwann cells units were hypermyelinated, and $3.2 \pm 2.5 \%$ hypermyelin structures with clear signs of degeneration were found. Some onion bulbs were present, but the variability between different animals was high $(3.7 \pm 3.4 \%)$; in one out of five mice analyzed, no onion bulbs were detectable. In 15-monthold animals, only $60.1 \pm 17.1 \%$ of the myelinated axon-Schwann cell units were not affected, and $20.8 \pm 9.8 \%$ appeared hypermyelinated. Degenerating hypermyelin structures $(6.6 \pm 3 \%)$ and onion bulbs $(10.9 \pm 7.7 \%)$ were often seen.

No significant differences in the number of hypermyelinated structures could be detected when the three age groups were compared (Fig. 5). Degenerating hypermyelin structures and onion bulb formation were first found at the age of 10 months. The prevalence of both structures was significantly increased in 15month-old PMP $22^{+/ 0}$ mice in comparison with 5-month-old mice, but interanimal variations were high, reminiscent of the clinical variability observed in older HNPP patients.

\section{Teased fiber analysis}

Teased nerve fibers of sural nerve biopsies have been used as a diagnostic method for hereditary motor and sensory neuropathies (Madrid and Bradley, 1975). To compare the observations made in HNPP with the PMP $22^{+/ 0}$ mouse model, we used the same experimental strategy to analyze affected internodal segments. Qualitative analysis of teased quadriceps nerve fiber preparations of 5-month-old PMP $22^{+/ 0}$ displayed focal hypermyelination at both inter- and paranodal regions (Fig. $6 b, c$ ), but paranodal tomacula appeared more frequently. Multiple tomacula within the same internodal segment and displaced myelin thickenings also were often found (Fig. 6c). In 10-month-old mutant mice, the presence of many very thick tomacula became obvious (Fig. $6 d$ ). In accordance with the corresponding electron microscopy analysis, these expanded structures were interpreted as the early onset of myelin degeneration of a former tomaculum (Fig. $2 f$ ). In 15-month-old PMP $22^{+/ 0}$ mice, thick tomacula were still a prominent feature, but segmental demyelination was also found at this age (Fig. 6e,f). Demyelinated internodal segments contained increased numbers of cell nuclei, presumably representing supernumerary Schwann cells forming onion bulbs (Fig. $6 f$ ).

Interestingly, teased nerve fibers of 10- and 15-month-old wildtype mice displayed a regular array of Schmidt-Lanterman incisures by light microscopy analysis (Fig. 7a), which was further highlighted by phalloidin staining (Gould et al., 1995) (Fig. 7c). In contrast, these regions of uncompacted myelin were severely disorganized in PMP $22^{+/ 0}$ littermates, and instead, a "twisted" network of putative cytoplasmic channels was suggested along the long axis of the axon (Fig. $7 b, d$ ).

\section{Statistical analysis of teased quadriceps nerve fibers}

Because of its limited resolution in the longitudinal axis, the analysis of cross sections does not allow detailed quantitative investigations into the progression of the nerve pathology from hypermyelination to demyelination in aging animals. To achieve the latter goal, we selected teased single fibers with abnormal myelin structures affecting nearly every internodal segment for 

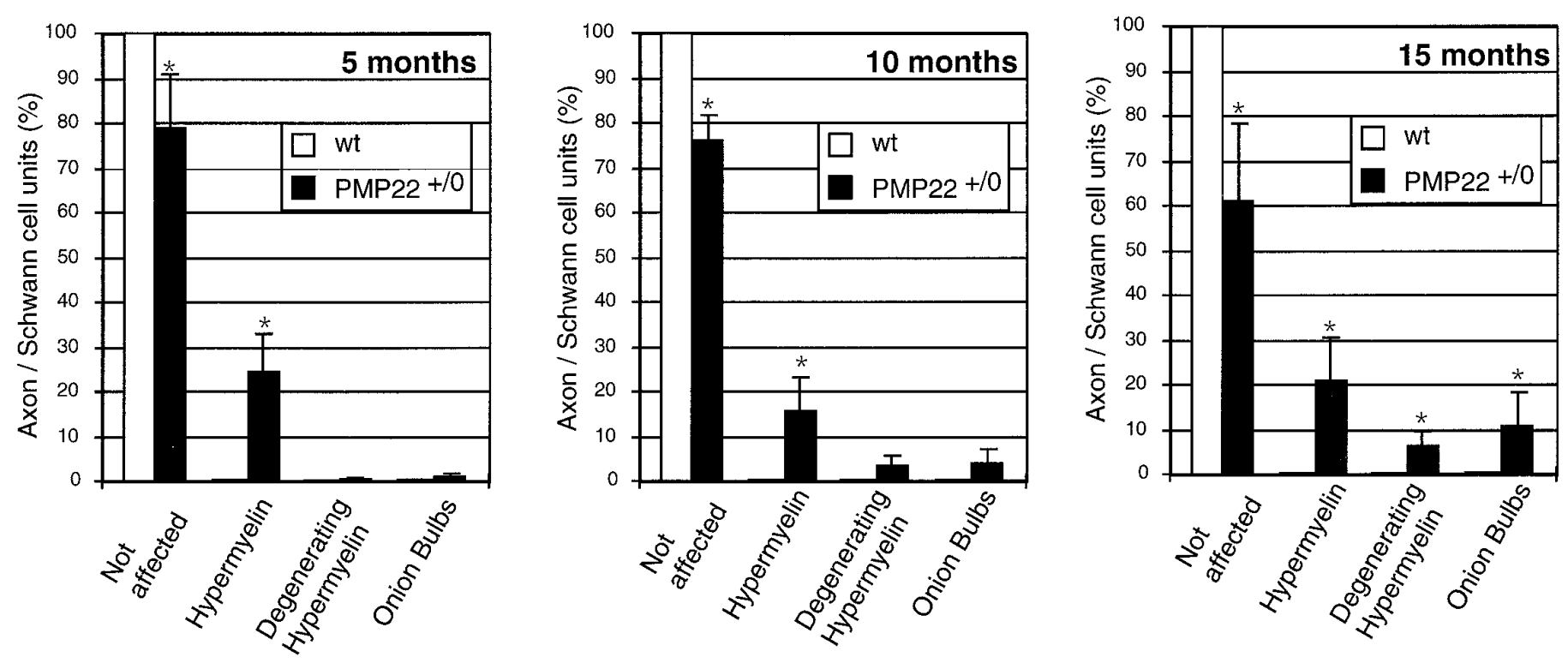

Figure 4. Quantitation of myelin abnormalities of PMP $22^{+/ 0}$ mice as deduced from electron microscopy analysis. Unaffected myelinated axon-Schwann cell units are significantly reduced in 5-month-old PMP $22^{+/ 0}$ mice, whereas hypermyelin structures are frequent. Degenerating tomacula and onion bulb formation were observed only rarely at this age. In 10-month-old PMP $22^{+/ 0}$ mice, degenerating tomacula and onion bulb formation occurred but did not reach statistical significance; however, all three myelin abnormalities were significantly increased in 15 -month-old PMP $22^{+/ 0}$ mice in comparison with wild-type littermates $\left({ }^{*} p \leq 0.05\right.$; one-sided $U$ test).

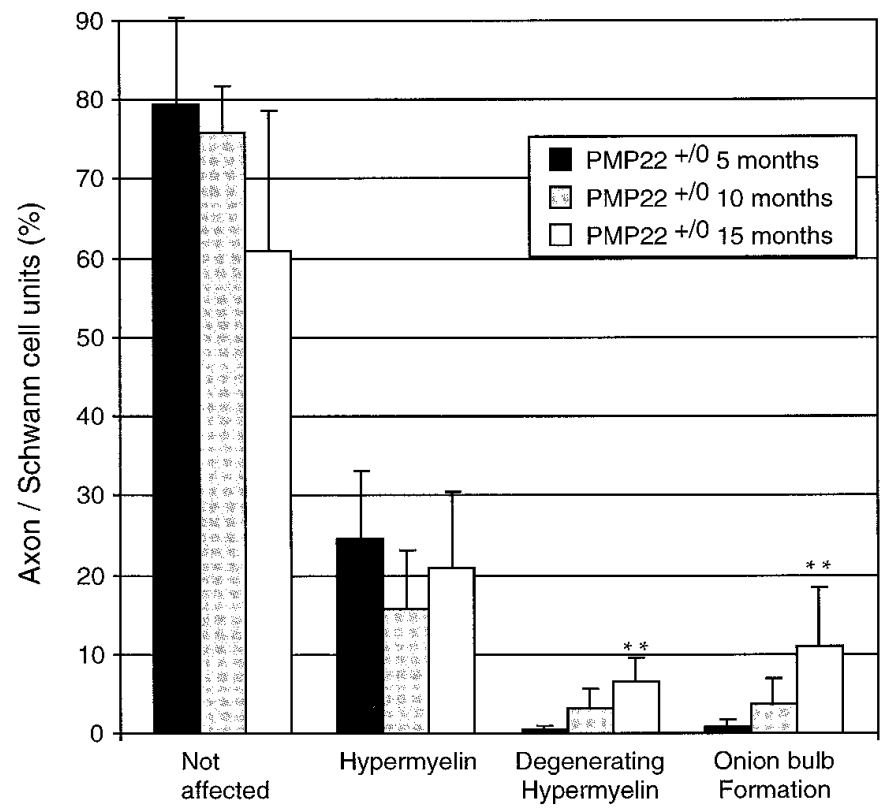

Figure 5. Age-related progression of myelin abnormalities in PMP22 $2^{+/ 0}$ mice deduced from electron microscopy analysis. The number of hypermyelin structures does not change significantly during aging of PMP $22^{+/ 0}$ mice, whereas degenerating hypermyelin and onion bulb formation were significantly increased in 15 -month-old PMP $22^{+/ 0}$ mice in comparison with 5 -month-old mutant mice ( ${ }^{* *} p \leq 0.01$; one-sided $U$ test).

quantitative analysis (Fig. 8). Approximately 100 affected internodal segments from each animal were counted, and the abnormalities in myelin structure were subdivided into tomacula, degenerating tomacula, and demyelination. For this analysis, internodal segments with one or more focal hypermyelin structures were classified as "tomacula" (Fig. 8). Segments containing degenerating tomacula (defined as strongly enlarged, irregular structures) appear as "degenerating tomacula," regardless of the presence of additional normal-shaped tomacula. Finally, internodal segments that showed established signs of demyelination were grouped under the heading "demyelination." Five animals were analyzed for each age group. Of the affected internodal segments in 5-month-old PMP $22^{+/ 0}$ mice, $88.8 \pm 4.1 \%$ (mean \pm SD) were associated with one or multiple tomacula (Fig. 8). In 10and 15-month-old mutant animals, tomaculous segments decreased significantly to $73 \pm 10.4 \%$ and $46 \pm 11.7 \%$, respectively. Degenerating tomacula were rarely detected in 5-month-old PMP $22^{+/ 0}$ animals $(3.8 \pm 3.1 \%)$, whereas in 10 -month-old animals, $16.9 \pm 13.6 \%$ of affected internodal segments contained degenerating tomacula; in 15-month-old animals, this percentage was increased significantly to $35.5 \pm 9.7 \%$. Limited demyelination was observed in young mutant animals, whereas in 15-month-old mice, $14.2 \pm 5.5 \%$ of internodal segments showed clear signs of demyelination. Interestingly, in PMP $22^{+/ 0}$ animals of all ages, mostly large caliber axons, presumably representing mainly motoneurons, were affected by myelin degeneration (data not shown).

\section{DISCUSSION}

In this report, we have characterized the morphological and electrophysiological alterations in peripheral nerves of transgenic mice carrying only one functional pmp 22 allele. Genetically, these mutant mice are models for the inherited human peripheral neuropathy HNPP, which is associated with a heterozygous deletion that includes the pmp22 locus (Suter and Snipes, 1995). Recent results indicate that the observed reduced PMP22 gene dosage is also reflected by a comparable reduction in the PMP22 protein concentration in the myelin sheath of PNS nerves of HNPP patients (Vallat et al., 1996). In complementation to the detailed descriptions of the clinical, electrophysiological, and pathological phenotype of HNPP (Meier and Moll, 1982), the availability of PMP $22^{+/ 0}$ mice allowed us to follow the particular features of a genetically 


\section{a PMP22wt}

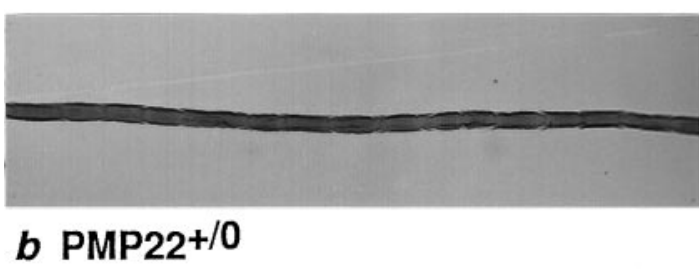

c PMP22+/0

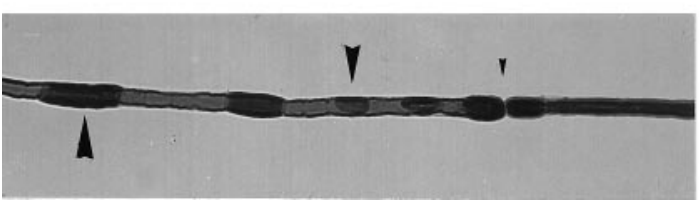

\section{d PMP22+/0}

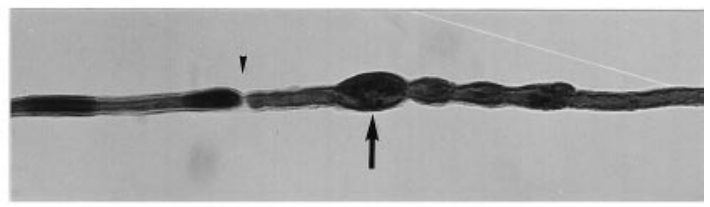

e PMP22+/0

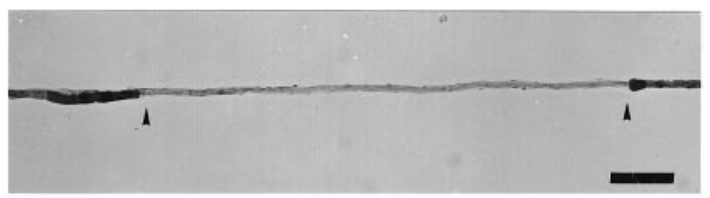

$f$ PMP22+/0

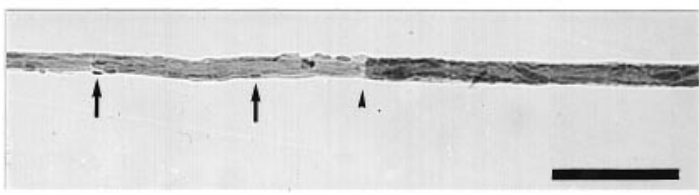

Figure 6. Morphology of teased nerve fibers from wild-type and PMP $22^{+/ 0}$ animals of different ages. Quadriceps nerve fibers in control animals (a). Paraand internodal tomacula in 5-month-old PMP $22^{+/ 0}$ animals $(b, c$, large arrowheads). In 10-month-old mutant animals, enlarged tomacula presumably undergoing degeneration are observed (d, large arrow). Demyelinated internodal segments are seen in 10-month-old PMP22 $2^{+/ 0}$ mice $(e)$, but their number is increased significantly in 15-month-old mutants $(f$, arrows indicate cell nuclei). Nodes of Ranvier are marked with small arrowheads $(b-f)$. Scale bars (shown in $f$ ): $a, c, d, f, 50 \mu \mathrm{m}$; (shown in $e$ ): $b, e, 50 \mu \mathrm{m}$.

\section{a PMP22 wt}

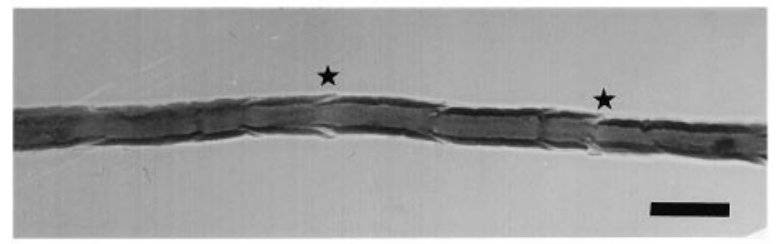

\section{b PMP22 +/0}

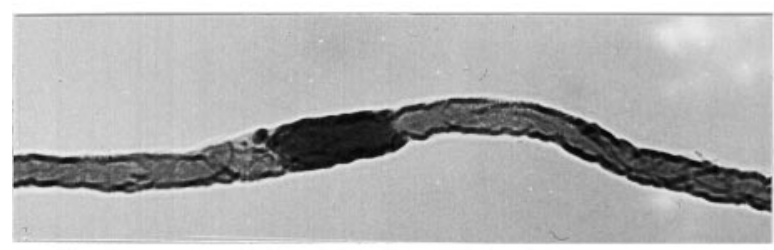

c PMP22 wt

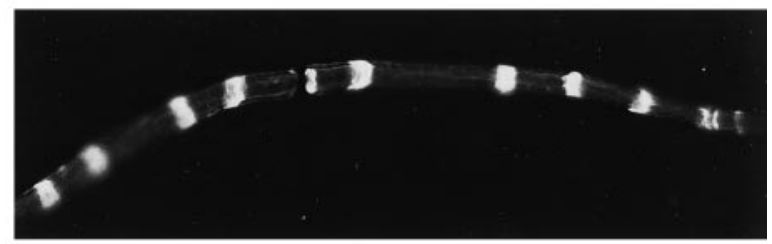

\section{d PMP22 +/0}

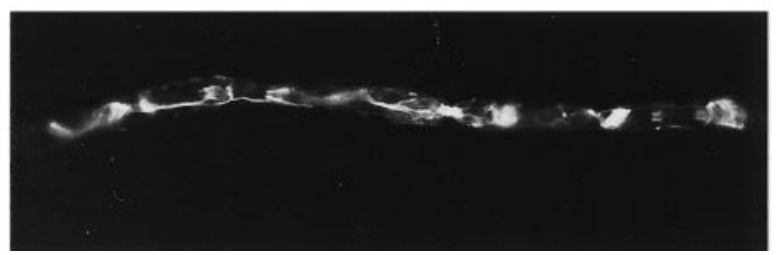

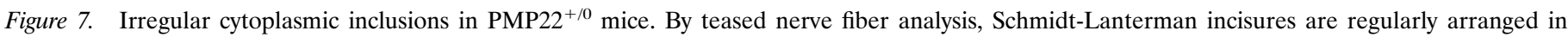

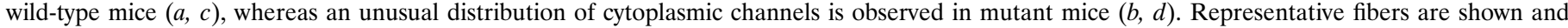

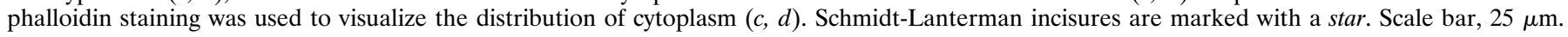

comparable disease in an animal model and to analyze disease progression in a defined manner.

Clinically, HNPP is characterized as a recurrent polyneuropathy in which acute focal paralysis may be precipitated by minor trauma to PNS nerves. The clinical progression and severity of the disease display high variability, and in specific cases, a chronic peripheral neuropathy may develop that is clinically indistinguishable from CMT (Windebank, 1993). In agreement with these findings, we have observed definitive signs of behavioral abnormalities indicative of a potential chronic peripheral neuropathy, such as unusual cramping of the hindlimbs, only occasionally and exclusively in aged PMP22 $2^{+/ 0}$ mice (data not shown). These observations are consistent with our electrophysiological analysis, which revealed significantly reduced amplitudes of the motor response in the foot muscles of PMP $22^{+/ 0}$ mice at $12-14$ months of age. In the absence of electrophysiological evidence of demyelination in our mice and in view of the histological findings, an M-response amplitude reduction indicates conduction failure only in the most severely affected fibers. In HNPP patients, persistent conduction block has been reported by several groups (Magistris and Roth, 1985; Sellman and Mayer, 1987). Motor amplitudes were abnormally low in $20-77 \%$ of nerves from HNPP patients with deletion of one PMP22 allele (Gouider et al., 1995). In contrast, electrophysiological signs of demyelination are mild (Meier and Moll, 1982; Oh, 1993; Gouider et al., 1995). A follow-up analysis in older mice is currently underway to investi- 


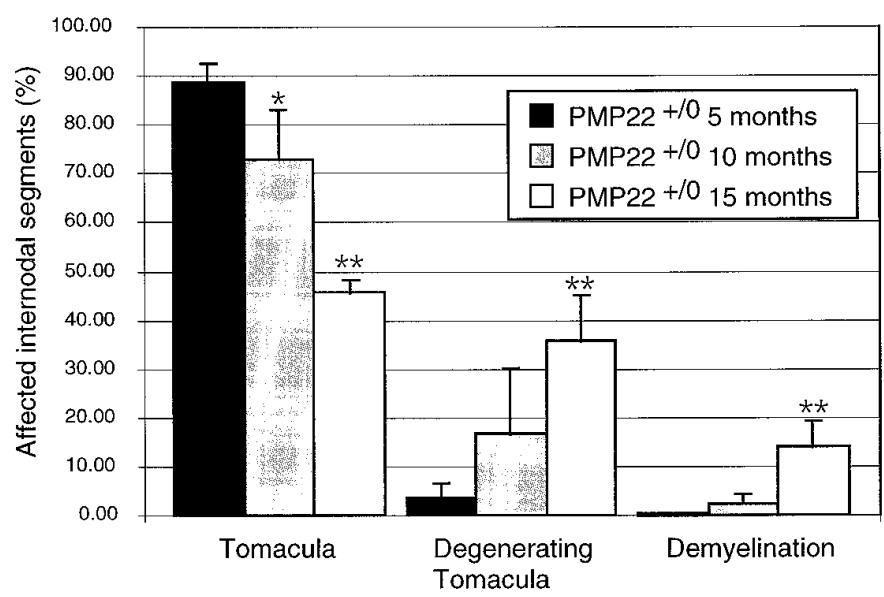

Figure 8. Progression of myelin abnormalities in affected internodal segments in teased nerve fibers of $\mathrm{PMP} 22^{+/ 0}$ mice. The number of tomaculous internodes decreases significantly with age. In contrast, an increase in degenerating tomacula is observed in 10- and 15-month-old PMP $22^{+/ 0}$ mice but reaches significance only at 15 months. The observed increase in onion bulb formation is significant at 15 months $\left({ }^{*} p \leq 0.05\right.$, ${ }^{* *} p \leq 0.01$; one-sided $U$ test).

gate whether demyelination will become electrophysiologically more evident later in life. Furthermore, given the slight but statistically not significant decrease of NCV in PMP $22^{+/ 0}$ mice, it will be important to examine the possibility of focal slowing. Interestingly, we did not detect marked F-wave abnormalities in PMP $22^{+/ 0}$ mice, which supports our observation that the extent of demyelination is rather mild. In contrast, we found more severe F-wave abnormalities in another animal model of a dysmyelinating neuropathy, the heterozygous $\mathrm{P} 0$-deficient mouse, which is affected by a more severe myelin deficiency (Zielasek et al., 1996).

Morphologically, HNPP is characterized as a tomaculous neuropathy with multifocal thickenings of the myelin sheath (Windebank, 1993). Similar to observations in human HNPP nerves, we found that para- and internodal tomacula were present in nearly every internode of large caliber axons in 5-month-old PMP $22^{+/ 0}$ mice. PNS nerves of 15 -month-old PMP $22^{+/ 0}$ mice, however, were affected not only by tomacula formation but also by the prominent presence of enlarged focal tomacula, suggesting degeneration. Furthermore, statistically significant demyelination and onion bulb formation were detectable at this age. Interestingly, focal myelin thickenings are not specific to HNPP, but they are also found in several other forms of peripheral neuropathies, including familial brachial plexus neuropathy, CMT1B, and chronic inflammatory demyelinating neuropathies (Dyck et al., 1993; Windebank, 1993; Thomas et al., 1994), suggesting that tomacula are unstable structures that may predispose to demyelination. This conclusion is supported by our findings in the quantitative analysis of teased peripheral nerve fibers derived from PMP $22^{+/ 0}$ mice, which indicates a reduction in the number of tomaculous internodal segments with a concomitant increase of demyelination.

Mice completely deficient of PMP22 (PMP22 $2^{0 / 0}$ ) display retarded myelination followed by prominent focal hypermyelination, and 2-month-old PMP22 ${ }^{\mathrm{o} / 0}$ animals show a CMT1-like phenotype with abundant onion bulb formation and axonal loss (Adlkofer et al., 1995). In comparison, PMP $22^{+/ 0}$ mice develop an increasing number of tomacula over the first 10 weeks, and signs of demyelination are not evident before the age of 10-15 months. Such a late onset of myelin deficiency is reminiscent of several other transgenic mouse strains that carry mutations in various myelin genes. In particular, $\mathrm{P} 0^{\mathrm{O} / 0}$ mice develop a severe phenotype that is characterized by hypomyelination and degeneration of myelin and axons at young age (Giese et al., 1992), but $\mathrm{P}^{+/ 0}$ mice are much less affected and reveal only a mild demyelination that is first detectable at the age of 4 months (Martini et al., 1995). These results suggest that $\mathrm{P} 0^{+/ 0}$ mice provide an accurate animal model for those cases of CMT1B that are associated with a P0 null allele (Warner et al., 1996; Suter, 1997). Furthermore, mutant mice devoid of $\mathrm{Cx} 32\left(\mathrm{C} x 32^{0 / 0}\right.$ or $\left.\mathrm{Cx} 32^{0 / y}\right)$ develop a late-onset demyelinating peripheral neuropathy, in agreement with the strong expression of Cx32 by myelinating Schwann cells, the presence of Cx32 in uncompacted PNS myelin, and frequent mutations found in this X-linked gene in CMTX1 (Paul, 1995; Anzini et al., 1997). Finally, mice deficient in the myelinassociated glycoprotein $\left(\mathrm{MAG}^{\mathrm{o} / 0}\right)$ also exhibit a late-onset peripheral nerve demyelination (Fruttiger et al., 1995). These combined findings suggest that the correct gene dosage of several myelinassociated genes is required for the maintenance of the PNS myelin sheath. Moreover, the distinct localizations and different putative functions of the various myelin proteins involved suggest that the classical morphological features of a demyelinating neuropathy can be the consequence of diverse molecular and cellular disease mechanisms.

None of the myelin mutants described so far, however, is characterized by a comparable degree of abundant focal hypermyelination as seen in PMP22-deficient animals. In particular, ageing PMP $22^{+/ 0}$ mice provide an excellent model for studying the different stages of tomacula formation and their subsequent degeneration. In these animals, tomacula seem to be stable structures until adulthood, with a late but distinct onset of demyelination. Our results indicate that tomacula can be generated by various mechanisms. One form of tomacula shows a regular structure and seems to be the direct consequence of too many ultrastructurally normal myelin lamellae surrounding the axon. A second class of tomacula may be related to the frequently observed initial invagination of myelin loops, which may lead to the formation of redundant internal loops of the myelin sheath.

Various spontaneous and transgenic rodent strains have revealed that PMP22 is involved in the initial spiralling of myelin in early development, the determination of myelin thickness, and the maintenance of myelin and axons of peripheral nerves (Suter et al., 1992a,b; Adlkofer et al., 1995; Magyar et al., 1996; Sereda et al., 1996). In vitro results further suggest that PMP22 is also involved in the control of Schwann cell proliferation and apoptosis (Fabbretti et al., 1995; Zoidl et al., 1995). Thus, whether the relative instability of tomacula is directly related to the function of PMP22 as a structural component of myelin or reflects a more general role of this protein in Schwann cell physiology remains an intriguing question.

Our results indicate that PMP $22^{+/ 0}$ mice closely mimic various aspects of the human hereditary neuropathy HNPP. Thus, these mice are likely to provide an excellent animal model for studying specific aspects of HNPP, in particular disease progression, and the induction and formation of tomacula followed by degeneration. It remains a challenge, however, to understand the reasons that induce a given Schwann cell to focally hypermyelinate an axon on the one hand, while on the other hand the rest of the internode appears quite normally myelinated. It is anticipated that PMP $22^{+/ 0}$ mice will not only provide a valuable tool for the search for the cellular disease mechanisms underlying HNPP but that 
this model will also be helpful in the evaluation and development of specific treatment strategies.

\section{REFERENCES}

Adlkofer K, Martini R, Aguzzi A, Zielasek J, Toyka KV, Suter U (1995) Hypermyelination and demyelinating peripheral neuropathy in pmp22deficient mice. Nature Genet 11:274-280.

Amato AA, Gronseth GS, Callerame KJ, Kagan-Hallet KS, Bryan WW, Barohn RJ (1996) Tomaculous neuropathy: a clinical and electrophysiological study in patients with and without $1.5-\mathrm{Mb}$ deletions in chromosome 17p11.2. Muscle Nerve 19:16-22.

Anzini P, Neuberg DH-H, Schachner M, Nelles E, Willecke K, Zielasek J, Toyka K, Suter U, Martini R (1997) Structural abnormalitites and deficient maintenance of peripheral nerve myelin in mice lacking the gap junction protein connexin 32. J Neurosci 17:4545-4551.

Chance PF, Alderson MK, Leppig KA, Lensch MW, Matsunami N, Smith B, Swanson PD, Odelberg SJ, Disteche CM, Bird TD (1993) DNA deletion associated with hereditary neuropathy with liability to pressure palsies. Cell 72:143-151.

Davies DM (1954) Recurrent peripheral nerve palsies in a family. Lancet 2:266-268.

De Jong JGY (1947) Over families met hereditaire disposite tot het optreten van neuritiden, gecorreladed met migraine. Psychiatr Neurol Bl (Amsterdam) 50:60-76.

Dyck PJ, Chance PF, Lebo RV, Carney JA (1993) Hereditary motor and sensory neuropathies. In: Peripheral neuropathy (Dyck PJ, Thomas PK, Griffin JW, Low PA, Poduslo JF, eds), pp 1094-1136. Philadelphia: WB Saunders.

Earl CJ, Fullerton PM, Wakefield GS, Schutta HS (1964) Hereditary neuropathy with liability to pressure palsies: a clinical and electrophysiological study of 4 families. Q J Med 33:481-498.

Fabbretti E, Edomi P, Brancolini C, Schneider C (1995) Apoptotic phenotype induced by overexpression of wild-type gas3/PMP22: its relation to the demyelinating peripheral neuropathy CMT1A. Genes Dev 9:1846-1856.

Fruttiger M, Montag D, Schachner M, Martini R (1995) Crucial role of the myelin-associated glycoprotein in the maintenance of axon-myelin integrity. Eur J Neurosci 7:511-515.

Giese KP, Martini R, Lemke G, Soriano P, Schachner M (1992) Mouse P0 gene disruption leads to hypomyelination, abnormal expression of recognition molecules, and degeneration of myelin and axons. Cell 71:565-576.

Gouider R, LeGuern E, Gugenheim M, Tardieu S, Maisonobe T, Leger JM, Vallat JM, Agid Y, Bouche P, Brice A (1995) Clinical, electrophysiologic, and molecular correlations in 13 families with hereditary neuropathy with liability to pressure palsies and a chromosome $17 \mathrm{p} 11.2$ deletion. Neurology 45:2018-2023.

Gould RM, Byrd AL, Barbarese E (1995) The number of SchmidtLanterman incisures is more than doubled in shiverer PNS myelin sheaths. J Neurocytol 24:85-98.

Lupski JR, Montes de Oca-Luna R, Slaugenhaupt S, Pentao L, Guzzetta V, Trask BJ, Saucedo-Cardenas O, Barker DF, Killian JM, Garcia CA, Chakravarti A, Patel PI (1991) DNA duplication associated with Charcot-Marie-Tooth disease type 1A. Cell 66:219-232.

Madrid R, Bradley WG (1975) The pathology of neuropathies with focal thickening of the myelin sheath (tomaculous neuropathy): studies on the formation of the abnormal myelin sheath. J Neurol Sci 25:415-488.

Magistris MR, Roth G (1985) Long-lasting conduction block in hereditary neuropathy with liability to pressure palsies. Neurology 35:1639-1641.

Magyar JP, Martini R, Ruelicke T, Aguzzi A, Adlkofer K, Dembic Z, Zielasek J, Toyka KV, Suter U (1996) Impaired differentiation of Schwann cells in transgenic mice with increased PMP22 gene dosage. J Neurosci 16:5351-5360.

Martini R, Schachner M, Faissner A (1990) Enhanced expression of the extracellular matrix molecule $\mathrm{J} 1 /$ tenascin in the regenerating adult mouse sciatic nerve. J Neurocytol 19:601-616.

Martini R, Zielasek J, Toyka KV, Giese KP, Schachner M (1995) Protein zero (P0)-deficient mice show myelin degeneration in peripheral nerves characteristic of inherited human neuropathies. Nature Genet 11:281-286.

Marvin KW, Fujimoto W, Jetten AM (1995) Identification and characterization of a novel squamous cell-associated gene related to PMP22. J Biol Chem 270:28910-28916.

Meier C, Moll C (1982) Hereditary neuropathy with liability to pressure palsies: report of two families and review of the literature. J Neurol 228:73-95.

Montag D, Giese KP, Bartsch U, Martini R, Lang Y, Bluthmann H, Karthigasan J, Kirschner DA, Wintergerst ES, Nave KA, Zielasek J, Toyka KV, Lipp H-P, Schachner M (1994) Mice deficient for the myelin-associated glycoprotein show subtle abnormalities in myelin. Neuron 13:229-246.

Oh SJ (1993) Nerve conduction in focal neuropathies. In: Clinical electromyography. Nerve conduction studies. (SJ Oh, ed), pp 496-574. Baltimore: Williams \& Wilkins.

Parmantier E, Cabon F, Braun C, D’Urso D, Müller HW, Zalc B (1995) Peripheral myelin protein-22 is expressed in rat and mouse brain and spinal cord motoneurons. Eur J Neurosci 7:1080-1088.

Patel PI, Roa BB, Welcher AA, Schoener-Scott R, Trask BJ, Pentao L, Snipes GJ, Garcia CA, Francke U, Shooter EM, Lupski JR, Suter U (1992) The gene for the peripheral myelin protein PMP-22 is a candidate for Charcot-Marie-Tooth disease type 1A. Nature Genet 1:159-165.

Paul DL (1995) New functions of gap junctions. Curr Opin Cell Biol 7:665-672.

Pentao L, Wise CA, Chinault AC, Patel PI, Lupski JR (1992) CharcotMarie-Tooth type 1A duplication appears to arise from recombination of repeat sequences flanking the 1.5 megabase monomer unit. Nature Genet 2:292-300.

Raeymaekers P, Timmerman V, Nelis E, De Jonghe P, Hoogendijk JE, Baas F, Barker DF, Martin JJ, De Visser M, Bolhuis PA (1991) Duplication in chromosome 17p11.2 in Charcot-Marie-Tooth neuropathy type 1a (CMT 1a): the HMSN Collaborative Research Group. Neuromuscul Disord 1:93-97.

Reiter LT, Murakami T, Koeuth T, Pentao L, Muzny DM, Gibbs RA, Lupski JR (1996) A recombination hotspot responsible for two inherited peripheral neuropathies is located near a mariner transposon-like element. Nature Genet 12:288-297.

Roa BB, Dyck PJ, Marks HG, Chance PF, Lupski JR (1995) Molecular diagnosis of CMT1A and HNPP. Lab Med Int 12:22-24.

Ruegg CL, Wu H-Y, Fagnoni FF, Engleman EG, Laus R (1996) B4B, a novel growth-arrest gene, is expressed by a subset of progenitor/ pre-B lymphocytes negative for cytoplasmic $\mu$-chain. J Immunol 157:72-80.

Sellman SM, Mayer RF (1987) Conduction block in hereditary neuropathy with liability to pressure palsies. Muscle Nerve 10:621-625.

Sereda M, Griffiths I, Pühlhofer A, Stewart H, Rossner MJ, Zimmermann F, Magyar JP, Schneider A, Hund E, Meinck H-M, Suter U, Nave K-A (1996) A transgenic rat model of Charcot-Marie-Tooth disease. Neuron 16:1049-1060.

Skre H (1974) Genetic and clinical aspects of Charcot-Marie-Tooth disease. Clin Genet 6:98-118.

Snipes GJ, Suter U, Welcher AA, Shooter EM (1992) Characterization of a novel peripheral nervous system myelin protein (PMP-22/SR13). J Cell Biol 117:225-238.

Staal A, de Weedt CJ, Went LN (1965) Hereditary compression syndrome of peripheral nerves. Neurology 15:1008-1017.

Suter U (1997) Myelin: Keeping nerves well wrapped up. Curr Biol 7:R21-R23.

Suter U, Snipes GJ (1995) Biology and genetics of hereditary motor and sensory neuropathies. Annu Rev Neurosci 18:45-75.

Suter U, Moskow JJ, Welcher AA, Snipes GJ, Kosaras B, Sidman RL, Buchberg AM, Shooter EM (1992a) A leucine-to-proline mutation in the putative first transmembrane domain of the $22 \mathrm{kDa}$ peripheral myelin protein in the trembler-J mouse. Proc Natl Acad Sci USA 89:4382-4386.

Suter U, Welcher AA, Ozcelik T, Snipes GJ, Kosaras B, Francke U, Billings-Gagliardi S, Sidman RL, Shooter EM (1992b) Trembler mouse carries a point mutation in a myelin gene. Nature 356:241-244.

Suter U, Welcher AA, Snipes GJ (1993) Progress in the molecular understanding of hereditary peripheral neuropathies reveals new insights into the biology of the peripheral nervous system. Trends Neurosci 16:50-56.

Taylor V, Suter U (1996) Epithelial membrane protein-2 and epithelial membrane protein-3: two novel members of peripheral myelin protein 22 gene family. Gene 175:115-120.

Taylor V, Welcher AA, AMGEN Est Program, Suter U (1995) Epithelial membrane protein-1, peripheral myelin protein 22 and lens membrane protein 20 define a novel gene family. J Biol Chem 270:28824-28833. 
Thomas FP, Lebo RV, Rosoklija G, Ding X-S, Lovelace RE, Latov N, Hays AP (1994) Tomaculous neuropathy in chromosome 1 CharcotMarie-Tooth syndrome. Acta Neuropathol 87:91-97.

Vallat JM, Sindou P, Preux PM, Tabaraud F, Milor AM, Couratier P, Le Guern E, Brice A (1996) Ultrastructural PMP22 expression in inherited demyelinating neuropathies. Ann Neurol 39:813-817.

Warner LE, Hilz MJ, Appel SH, Killian JM, Kolodny EH, Karpati G, Carpenter S, Watters GV, Wheeler C, Witt D, Bodell A, Nelis E, Van Broeckhoven C, Lupski JR (1996) Clinical phenotypes of different MPZ (P0) mutations may include Charcot-Marie-Tooth type 1B, Dejerine-Sottas, and congenital hypomyelination. Neuron 17:451-460. Welcher AA, Suter U, De Leon M, Snipes GJ, Shooter EM (1991) A myelin protein is encoded by the homologue of a growth arrest-specific gene. Proc Natl Acad Sci USA 88:7195-7199.

Windebank AJ (1993) Inherited recurrent focal neuropathies. In: Peripheral neuropathy (Dyck PJ, Thomas PK, Griffin JW, Low PA, Poduslo JF, eds), pp 1137-1148. Philadelphia: Saunders.

Zielasek J, Martini R, Toyka KV (1996) Functional abnormalities in $\mathrm{P} 0$-deficient mice resemble human hereditary neuropathies linked to P0 gene mutations. Muscle Nerve 19:946-952.

Zoidl G, Blass-Kampmann S, D'Urso D, Schmalenbach C, Müller HW (1995) Retroviral-mediated gene transfer of the peripheral myelin protein PMP22 in Schwann cells: modulation of cell growth. EMBO J $14: 1122-1128$ 